\title{
Discrimination of Picea chihuahuana Martinez populations on the basis of climatic, edaphic, dendrometric, genetic and population traits
} \author{
Heinze $^{2}$, José Ángel Prieto-Ruiz ${ }^{3}$, Christian Wehenkel ${ }^{\text {Corresp. } 1}$ \\ 1 Instituto de Silvicultura e Industria de la Madera, Universidad Juárez del Estado de Durango, Durango, Mexico \\ 2 Federal Research Centre for Forests, Natural Hazards and Landscape (BFW), Vienna, Austria \\ 3 Facultad de Ciencias Forestales, Universidad Juárez del Estado de Durango, Durango, Mexico \\ Corresponding Author: Christian Wehenkel \\ Email address: wehenkel@ujed.mx
}

Iliana Karina Dominguez-Guerrero ${ }^{1}$, Samantha Mariscal-Lucero ${ }^{1}$, José Ciro Hernández-Díaz ${ }^{1}$, Berthold

Background. Picea chihuahuana, which is endemic to Mexico, is currently listed as "Endangered" on the Red List. Chihuahua spruce is only found in the Sierra Madre Occidental (SMO), Mexico. About 42,600 individuals are distributed in forty populations.

These populations are fragmented and can be classified into three geographically distinct clusters in the SMO. The total area covered by $P$. chihuahuana populations is less than 300 ha. A recent study suggested assisted migration as an alternative to the ex situ conservation of $P$. chihuahuana, taking into consideration the genetic structure and diversity of the populations and the predictions regarding the future climate of the habitat. However, detailed background information is required to enable development of plans for protecting and conserving species and for successful assisted migration. Thus, it is important to identify differences between populations in relation to environmental conditions. The genetic diversity of populations, which affect vigor, evolution and adaptability of the species, must also be considered. In this study, we examined 14 populations of $P$. chihuahuana, with the overall aim of discriminating the populations and form clusters of this species. Methods. Each population was represented by one $50 \times 50$ $\mathrm{m}$ plot established in the center of its respective location. Climate, soil, dasometric, density variables and genetic and species diversities were assessed in these plots for further analyses. The putatively neutral and adaptive AFLP markers were used to calculate genetic diversity. Affinity Propagation (AP) clustering technique and $k$-means clustering algorithm were used to classify the populations in the optimal number of clusters. Later stepwise binomial logistic regression was applied to test for significant differences in variables of the southern and northern $P$. chihuahuana populations. Spearman's correlation test was used to analyze the relationships among all variables studied. Results. The binomial logistic regression analysis revealed that seven climate variables, the 
geographical longitude and sand proportion in the soil separated the southern from northern populations. The northern populations grow in more arid and continental conditions and on soils with smaller sand. The mean genetic diversity using all AFLP studied of $P$. chihuahuana was significantly correlated with the mean temperature in the warmest month, where warmer temperatures are associated to larger genetic diversity. Genetic diversity of $P$. chihuahuana calculated with putatively adaptive AFLP was not statistically significantly correlated with any environmental factor. Discussion. Future reforestation programs should take into account that at least two different groups (the northern and southern cluster) of $P$. chihuahuana probably exist, as local adaptation may take place because of different environmental conditions. 


\title{
Discrimination of Picea chihuahuana Martinez populations on the basis of climatic, edaphic, dendrometric, genetic and population traits
}

\author{
Iliana Karina Dominguez-Guerrero ${ }^{1}$, Samantha Mariscal-Lucero ${ }^{1}$, José Ciro Hernández-Díaz ${ }^{1}$, \\ Berthold Heinze $^{2}$, José Ángel Prieto-Ruiz ${ }^{3}$, Christian Wehenkel ${ }^{1 *}$ \\ ${ }^{1}$ Instituto de Silvicultura e Industria de la Madera, Universidad Juárez del Estado de Durango, Durango, México. \\ ${ }^{2}$ Federal Research Centre for Forests, Natural Hazards and Landscape (BFW), Department of Genetics, Wien, \\ Austria. \\ ${ }^{3}$ Facultad de Ciencias Forestales, Universidad Juárez del Estado de Durango, Durango, México. \\ Corresponding author: wehenkel@ujed.mx
}

\begin{abstract}
\end{abstract}
Background. Picea chihuahuana, which is endemic to Mexico, is currently listed as "Endangered" on the IUCN Red List. Chihuahua spruce is only found in the Sierra Madre Occidental (SMO), Mexico. About 42,600 individuals are distributed in forty populations. These populations are fragmented and can be classified into three geographically distinct clusters in the SMO. The total area covered by $P$. chihuahuana populations is less than 300 ha. A recent study suggested assisted migration as an alternative to the ex situ conservation of $P$. chihuahuana, taking into consideration the genetic structure and diversity of the populations and the predictions regarding the future climate of the habitat. However, detailed background information is required to enable development of plans for protecting and conserving species and for successful assisted migration. Thus, it is important to identify differences between populations in relation to environmental conditions. The genetic diversity of populations, which affect vigor, evolution and adaptability of the species, must also be considered. In this study, we examined 14 populations of $P$. chihuahuana, with the overall aim of discriminating the populations and form clusters of this species.

Methods. Each population was represented by one 50 x $50 \mathrm{~m}$ plot established in the center of its respective location. Climate, soil, dasometric, density variables and genetic and species diversities were assessed in these plots for further analyses. The putatively neutral and adaptive AFLP markers were used to calculate genetic diversity. Affinity Propagation (AP) clustering technique and $k$-means clustering algorithm were used to classify the populations in the optimal number of clusters. Later stepwise binomial logistic regression was applied to test for significant differences in variables of the southern and northern $P$. chihuahuana populations. Spearman's 
34 correlation test was used to analyze the relationships among genetic diversity, climatic, soil, 35 dasometric, density and population variables.

36 Results. The binomial logistic regression analysis revealed that seven climate variables, the 37 geographical longitude and sand proportion in the soil separated the southern from northern populations. The northern populations grow in more arid and continental conditions and on soils with smaller sand. The mean genetic diversity using all AFLP studied of P. chihuahuana was significantly correlated with the mean temperature in the warmest month, where warmer temperatures are associated to larger genetic diversity. Genetic diversity of $P$. chihuahuana calculated with putatively adaptive AFLP was not statistically significantly correlated with any environmental factor.

Discussion. Future reforestation programs should take into account that at least two different groups (the northern and southern cluster) of $P$. chihuahuana probably exist, as local adaptation may take place because of different environmental conditions. 


\section{Introduction}

Picea chihuahuana Mtz. (Chihuahua spruce), which is endemic to Mexico, is currently listed as "Endangered" on the Red List of the International Union for the Conservation of Nature and Natural Resources (IUCN, 2013) and in the official Mexican normativity on endangered species (NOM-059-SEMARNAT-2010) (SEMARNAT, 2010). This tree species grows at elevations between 2,150 and 2,990 $\mathrm{m}$ in areas with mean annual temperatures of $9-12{ }^{\circ} \mathrm{C}$ and precipitation ranging from around $600 \mathrm{~mm}$ to $1,300 \mathrm{~mm}$ (provenance's climate inferred from Sáenz-Romero et al., 2010).

Chihuahua spruce is only found in the Sierra Madre Occidental (SMO), Mexico. About 42,600 individuals are distributed in forty populations (Farjon, Page \& Schellevis, 1993; Ledig et al., 2000; Wehenkel \& Sáenz-Romero, 2012). The species is specifically located in the states of Chihuahua (in the municipalities of Bocoyna, Temosachi, Guerrero, and Balleza) and Durango (in the municipalities of El Mezquital, Pueblo Nuevo, San Dimas, Canelas, and Guanacevi) (Ledig et al., 2000). The populations are fragmented and can be classified into three geographical clusters in the SMO of the two States (south, center, and north), each group separated by a distance of about $300 \mathrm{~km}$ (Mendoza-Maya et al., 2015). The total accumulated area covered by Chihuahua spruce populations is less than 300 ha (Simental-Rodríguez et al., 2014). Almost all P. chihuahuana populations are located on creeks or rivers and from north-east to north-west facing slopes (Ledig et al., 2000). P. chihuahuana is commonly associated with species of the genera Pinus and Quercus, and occasionally with species of the genera Abies, Pseudotsuga, Cupressus, Populus, Juniperus, and Prunus (Gordon, 1968; Wehenkel et al., 2015a).

Previous studies have stated the hypothesis that populations of $P$. chihuahuana collapsed during the Holocene warming, with a significant reduction of their effective population size (Jaramillo-Correa et al., 2006). This rare species is economically unimportant as a timber tree; however, large mature trees were harvested sometime in the past (Thomas \& Farjon, 2013). Grazing and forest fires have also contributed to reduce population sizes (Ledig et al., 1997). Currently, several other factors also threaten P. chihuahuana populations, including the low reproductive capacity resulting from high levels of self-fertilization and mating between closely related individuals (Ledig et al., 1997). Recent research revealed problems of genetic erosion in one population, San José de las Causas (Wehenkel \& Saenz-Romero, 2012). 
Different approaches have been used to study Picea chihuahuana from the perspectives 90 of ecology (Narváez, 1984; Ledig et al., 2000), genetic structure (Ledig et al., 1997; Jaramillo91 Correa et al., 2006; Wehenkel et al., 2012; Wehenkel \& Saenz-Romero, 2012; Quiñones-Pérez, 92 Sáenz-Romero \& Wehenkel, 2014; Quiñones-Pérez et al., 2014; Wehenkel, Sáenz-Romero \& 93 Jaramillo-Correa, 2015b), and climate change (Ledig et al., 2010).

In a recent study, Mendoza-Maya et al. (2015) suggested assisted migration as an alternative to the ex situ conservation of $P$. chihuahuana, taking into consideration the genetic structure and diversity of the populations and also predictions regarding the future climate of the habitat. However, detailed background information is required to enable development of plans for protecting and conserving species and in order to achieve successful assisted migration. Thus, it is important to identify differences between populations in relation to environmental conditions (Aguilar-Soto et al., 2015). The vitality and genetic diversity of populations, which affect vigor, evolution, and adaptability of the species, must also be considered (Frankham, Ballou \& Briscoe, 2002; Reed \& Frankham, 2003). In other words, genetic diversity is vital for increasing population fitness by reducing inbreeding depression in the short term and, in the longer term, to develop new local adaptations in response to environmental changes (Reed \& Frankham, 2003). Genetic diversity also affects ecological processes such as primary productivity, population recovery from disturbances, interspecific competition, community structure, and fluxes of energy and nutrients (Hughes et al., 2008). AFLP markers (amplified fragment length polymorphism) can be used to describe genetic diversity (Meudt \& Clarke, 2007). Outlier AFLP markers were found in several studies (e.g. Nunes, Beaumont \& Butlin, 2012), that were associated with different abiotic and biotic conditions (e.g., Jump et al., 2006, Wehenkel et al., 2010).

In this study, we examined fourteen $P$. chihuahuana populations with the overall aim of discriminating the populations and clusters of this unique tree species. For this purpose we: i) determined 74 variables: 22 climatic, 27 edaphic, 10 dasometric, four density variables and other two population variables, as well as six genetic variables and three species diversity indices were tested by using putatively neutral and adaptive AFLP markers, ii) identified suitable variables for separating populations, and iii) tested for correlation between genetic diversity, dasometric, and environmental factors. Our purpose was seeking for any significant differences, in order to 
118 predict species distribution by discriminant analysis; the results led us to make proposals for ex

119 situ conservation of P. chihuahuana.

\section{Materials and methods}

\section{Study area}

122 The study was conducted in 14 populations of $P$. chihuahuana located in five municipalities of 123 the state of Durango and two municipalities of Chihuahua, Mexico (Table 1 and Fig. 1). The 14 124 locations were selected in order to cover three geographically distinct clusters of the natural 125 distribution along the species (north, center, and south). Each location was represented by one 50 $126 \times 50 \mathrm{~m}(0.25 \mathrm{ha})$ plot established in the center of the respective population. Following Wehenkel 127 et al. (2015a), all trees with diameter at breast height (DBH) $\geq 7.5 \mathrm{~cm}$ were scored in regard to 128 position, DBH, height, and species affiliation. Field experiments were approved by the 129 Secretariat of Environment and Natural Resource, Mexico (SEMARNAT; permit number 130 SGPA/DGVS/02835/12).

\section{Determination of climate variables}

132

133

134

135

136

137

138

139

140

141

142

143

144

The climate model developed by Rehfeldt (2006), based on thin plate spline (TPS) of Hutchinson (1991, 2004), and explained for its Mexican implementation by Sáenz-Romero et al. (2010), was used to estimate 22 climate variables in each population. This model yielded data from standardized monthly mean, minimum, and maximum values of temperature and precipitation from more than 200 climate stations in Chihuahua and Durango, for the period 1961-1990. Point estimates of climate measures were obtained from a national database managed by the University of Idaho (http://forest.moscowfsl.wsu.edu/climate/), for which the geographical coordinates (latitude, longitude, and elevation) are required as input data to interrogate the climate splines. Estimation of variables included: mean annual precipitation $(\mathrm{mm})$, mean temperature in the warmest month $\left({ }^{\circ} \mathrm{C}\right)$, mean maximum temperature in the warmest month $\left({ }^{\circ} \mathrm{C}\right)$, Julian date of the first freezing date of autumn, and precipitation during the growing season (April to September) (mm) (Table 2).

\section{Determination of edaphic variables}


In each location, a soil subsample $(250 \mathrm{~g})$ was collected at a depth of 0 to $15 \mathrm{~cm}$ at the

146

147

148

149

150

151

152

153

154

155

156

157

158

159

160

161

162

163

164

165

166

167

168

169

170

171

172

173

174

base of the stems of four Picea chihuahuana trees. The four soil subsamples were combined to make a 1,000 g sample per population (14 samples in total) for analysis of 27 edaphic variables:

The texture (relative proportion of sand, silt, and clay), hydraulic conductivity $(\mathrm{HC})(\mathrm{cm} / \mathrm{h})$, density (Den) $\left(\mathrm{gr} / \mathrm{cm}^{3}\right)$, concentration of calcium carbonate $\left(\mathrm{CaCO}_{3}\right)(\%), \mathrm{pH}\left(\mathrm{CaCl}_{2}, 0.01 \mathrm{M}\right)$, concentrations of potassium $(\mathrm{K})(\mathrm{ppm})$, magnesium $(\mathrm{Mg})(\mathrm{ppm})$, sodium $(\mathrm{Na})(\mathrm{ppm})$, copper $(\mathrm{Cu})$ (ppm), iron (Fe) (ppm), manganese (Mn) (ppm), zinc (Zn) (ppm), and calcium (Ca) (ppm) in the soil were determined by the methods described by Castellanos, Uvalle-Bueno \& AguilarSantelises (1999). Phosphorus (P) (ppm) was determined by the method of Olsen et al. (1954). Nitrate $\left(\mathrm{NO}_{3}\right)(\mathrm{kg} / \mathrm{ha})$ was determined by the method of Baker (1967) and the relative organic matter (\%) (OM) contents were determined by the method of Leon \& Aguilar (1987). Electrical conductivity (CE) $(\mathrm{dS} / \mathrm{m})$ was determined by the method described by Vazquez \& Bautista (1993). Finally, the cation exchange capacity (meq $100 \mathrm{~g}$ soil) (CEC) and the relative proportions (\%) of hydrogen, $\mathrm{Ca}, \mathrm{M}, \mathrm{K}, \mathrm{Na}$ and other bases (o.b.) in the CEC were estimated on the basis of the Ammonium Acetate Method ( $\mathrm{pH}$ 8.5). The hydraulic conductivity (HC) $(\mathrm{cm} / \mathrm{h})$ was determined by the method of Mualem (1976) and percent saturation (Sat) (\%) was estimated by the method of Herbert (1992). Edaphic variables are described in Table 3.

\section{Determination of dasometric, density and population variables}

For each of the 14 plots we estimated the basal area $(\mathrm{G})$, diameter at breast height (DBH), height $(\mathrm{H})$, maximum diameter at breast height $\left(\mathrm{DBH}_{\max }\right)$, maximum height $\left(\mathrm{H}_{\max }\right)$ of $P$. chihuahuana trees. For each plot we also estimated the following variables considering together all tree species found per plot (see details in Wehenkel et al., 2015a): total diameter at breast height $\left(\mathrm{DBH}_{\mathrm{tot}}\right)$ and total height $\left(\mathrm{H}_{\mathrm{tot}}\right)$. Besides we registered the total maximum diameter at breast height for all tree species per plot $\left(\mathrm{DBH}_{\text {max,tot }}\right)$ and total maximum height for all tree species found per plot $\left(\mathrm{H}_{\text {max,tot }}\right)$, according to Assmann (1970). We also estimated the total number of individuals of $P$. chihuahuana per plot $(\mathrm{N})$, quadratic $\mathrm{DBH}$ of $P$. chihuahuana per plot $\left(D_{g}\right)$, total number of individuals per plot $\left(\mathrm{N}_{\text {tot }}\right)$, basal area per plot $\left(\mathrm{G}_{\text {tot }}\right)$ and quadratic $\mathrm{DBH}$ per plot $\left(\mathrm{D}_{\mathrm{g}, \mathrm{tot}}\right)$, according to Wehenkel et al. (2015a) (Table 4). Two other population variables were considered: Population size (T) and geographical distance between neighbor populations $\left(d_{\text {min }}\right)$. T was taken from Table 6 of Ledig et al. (2000). $d_{\min }$ was calculated by GenAlex 6.5 
175 (Peakall \& Smouse, 2006) (Table 1). All the 40 known populations, based on their geographical 176 coordinates (Table 1), were included for the distance calculations.

\section{Determination of genetic diversity variables}

178 Needles were sampled from 669 individuals (seedling, saplings and trees) of $P$. 179 chihuahuana in the 14 populations (plots) studied (i.e. 17-57 individuals per plot), for 180 determination of genetic diversity variables (Table 5).

181

182

183

184

185

186

187

188

189

190

191

192

193

194

195

196

197

198

199

200

201

The DNA was extracted using the DNeasy 96 Plant Kit (QIAGEN, Hilden, Germany). The amplified fragment length polymorphism (AFLP) analysis was conducted according to a modified version of the protocol of Vos et al. (1995), described by Simental-Rodríguez et al. (2014). The restriction enzymes used were Eco RI (selective primer: 5'GACTGCGTACCAATTCNNN-3') and Mse I (selective primer: 5'GATGAGTCCTGAGTAANNN-3'). The primer combination E01/M03 (EcoRI-A/MseI-G) was used in the pre-AFLP amplification. Selective amplification was carried out with the fluorescentlabelled (FAM) primer pair E35 (EcoRI-ACA) and M70 (MseI-GCT). The AFLP products were separated in an ABI 3100 Genetic Analyzer, along with the GeneScan 500 ROX internal lane size standard (Applied Biosystems, Foster City, California, U.S.A.). Selection of the amplified restriction products was totally automated, and only strong and high quality fragments were considered. The size of the AFLP fragments was determined with the GeneScan ${ }^{\circledR} 3.7$ and Genotyper® 3.7 software packages (Applied Biosystems, Foster City, California, U.S.A.). Binary AFLP matrices were created from the presence (code 1) or absence (code 0) at probable fragment positions. The quality and reproducibility of the analysis were verified according to Ávila-Flores et al. (2016).

The AFLP data were used to calculate three genetic diversity indices (Table 5): the modified frequency-down-weighted marker value (DW), the polymorphism percentage (POLY) (Schönswetter \& Tribsch, 2005), and, the mean genetic diversity $\left(\mathrm{v}_{2}\right)$; this last one was determined according to Gregorius (1978),

$$
\mathrm{V}_{2, j}=\left(\frac{1}{N}\right) * \sum\left(\frac{1}{\sum p_{i j}^{2}}\right)
$$


202 where: $p_{i j}$ is the relative frequency of a variant from the $i$ to the $j$ locus and $N$ is the sample 203 number.

204

205

206

207

The value of DW is expected to be high when rare AFLPs are accumulated (Schönswetter \& Tribsch 2005). In order to equalize dissimilar sample sizes, the values of the three diversity indices were multiplied by a correction term (N/(N-1)), (Gregorius, 1978).

The values of these three genetic diversity indices were also calculated for putatively adaptive AFLP markers under natural selection (adaptive AFLP), detected in P. chihuahuana by Simental-Rodríguez et al. (2014).

The values of tree species richness $\left(v_{\mathrm{sp}, 0}\right)$, Simpson index $\left(v_{\mathrm{sp}, 2}\right)$, and number of prevalent tree species $\left(v_{\text {sp,inf }}\right)$ in the 14 plots were taken from Simental-Rodríguez et al. (2014) who used the same sampling strategy as in the present study (Table 5).

\section{Cluster analysis}

First, in order to detect the optimal cluster set for population conditions which were almost homogeneous inside each cluster, but clearly different from any other clusters, we used the recent Affinity Propagation (AP) clustering technique, with the input preference to the 0 quantile (q) of the input similarities (Bodenhofer, Kothmeier \& Hochreiter, 2011), along with the $k$-means clustering algorithm ( $k$-means) (Hartigan and Wong, 1979). We also utilized the CalinskiHarabasz criterion $(\mathrm{CHC})$ to determine the optimal number of clusters. $\mathrm{CHC}$ minimizes the within-cluster sum of squares and maximizes the between-cluster sum of squares. Therefore, the highest $\mathrm{CHC}$ value is related to the optimal set (of most compact clusters). The optimal set can be identified by a peak or at least an abrupt elbow on the linear plot of $\mathrm{CHC}$ values (Legendre and Legendre, 1998).

By contrast to the $k$-means, the conceptually new AP simultaneously includes all data points as potential exemplars. Furthermore, AP has several advantages over related techniques, such as $k$-centres clustering, the expectation maximization (EM) algorithm, Markov chain Monte Carlo procedures, hierarchical clustering and spectral clustering (see details in Frey and Dueck 2007). More importantly, it does not need a pre-defined number of groups (Bodenhofer, Kothmeier \& Hochreiter, 2011).

For all the $P$. chihuahuana populations, both the AP $(q=0)$ technique and the $k$-means 
231 clustering along with CHC were firstly applied to all the 74 predictor variables together, and then

232 separately for the 22 climate variables, 27 soil variables, nine genetic and species diversity 233 variables, 10 dasometric variables, four density variables, $\mathrm{T}$ and $\mathrm{d}_{\min }$ (Tables 2, 3, 4 and 5).

All analyses were implemented using the $\mathrm{R}$ Script for $k$-Means Cluster Analysis and

235

236

237

238

239

240

241

242

243

244

245

246

247

248

249

250

251

252

253

254

255

256

257

258

"apcluster" software packages (Bodenhofer, Kothmeier \& Hochreiter, 2011) executed in the free statistical application R (Development Core Team, 2015).

The AP and $k$-means clustering techniques recommended only two clusters of $P$. chihuahuana populations under study, which were completely separated from each other by the latitude and several other predictor variables.

\section{Principal component analysis and logistic regression}

Stepwise binomial multivariate logistic regression was used, which accepts independent variables even with heteroscedasticity and without a multivariate normal distribution (Hosmer, Lemeshow \& Sturdivant, 2013). This regression tested for significant differences in climatic, dasometric, soil, genetic and species diversity variables between the southern populations (value zero) and the northern (value one) populations of $P$. chihuahuana (Table 1). The R software (version 3.3.2) was used to conduct the analysis. A linear discrimination analysis (Fisher, 1936) was not applied, since not every independent variable was normally distributed.

From the 74 predictor variables in Tables 1-5 only those that were not highly correlated with other predictor variables were included, because logistic regression requires each variable to be independent from each other (i.e., little or no multicollinearity). These predictor variables were found applying a varimax-rotated Principal Component Analysis (PCA) (Pearson, 1901). Therefore, only one variable from each PCA factor and with the highest factorial loads was selected for logistic regression.

Variables were excluded from the models if the probability of incorrectness $(p)$ was greater than or equal to $5 \%$. Stepwise selection (forward and backward) was performed to select the most informative variables for inclusion in the models. This procedure was done using the glm (generalized linear model) (family = "binomial"), the step AIC (Akaike information criterion) function and the exact AIC using the "MASS" package (Venables and Ripley, 2002) in R 
259 (Development Core Team, 2015). The AIC, standard error (SE) and residual deviance were used 260 to evaluate the goodness-of-fit.

261

262

263

264

265

266

267

268

269

270

271

272

273

274

275

276

277

278

279

280

281

282

283

284

285

286

\section{Ordinary kriging analysis}

Ordinary kriging (ordinary Gaussian process regression model) was used to illustrate the spatial genetic distribution of genetic diversities ( $v_{2}$, POLY, and DW) in P. chihuahuana (Batista et al., 2016). The mathematical models for describing the semivariance were: the spherical model, exponential model, Gaussian model, and Stein's parameterization. The best interpolation model was detected using 10-fold cross validation point-by-point. Correlation between the observed and predicted values $\left(r_{k}\right)$ and the Unbiased Root Mean Squared Error of the residual (URMSE) were used to assess the goodness-of-fit. Finally, the model with the best fit was selected to create the prediction surface map of genetic diversity.

This modeling was realized using the CRS, SpatialPixelsDataFrame, autoKrige, autoKrige.cv, and compare.cv functions and using the "SP" (Pebesma and Bivand 2005) and “automap" packages (Hiemstra et al. 2009) in R (Development Core Team, 2015).

\section{Spearman correlations}

Spearman's correlation $\left(\mathrm{r}_{\mathrm{s}}\right)$ test (Hauke \& Kossowski, 2011) was used to analyze the relationships between genetic diversity and the climatic, soil, dasometric variables, $\mathrm{d}_{\min }$ and $\mathrm{T}$. The test was implemented using R 3.2.3 statistical software (R Core Team, 2015). A Bonferroni correction was applied to calculate the new critical significance level $\left(\alpha^{*}=0.00023\right)$, by dividing the proposed critical significance level $(\alpha=0.05)$ by the number of comparisons $(\mathrm{m}=213)$ (Hochberg, 1988).

\section{Results}

\section{Cluster analysis}

The Affinity Propagation clustering technique and the $k$-means clustering algorithm recommended two clusters based on the 74 predictor variables; the same grouping was found by using only the 22 climate variables under study (Fig. 2). The first cluster included the nine most northern $P$ chihuahuana populations under study (TN, RC, CV, TY, TR, VN, LQ, PPR and QD). While the second group comprised the five most southern populations (CB, SJ, SB, ACH and 
287 LP) (Table 1, Fig. 1). A cluster analyses was also applied with respect to the 27 soil variables, six 288 genetic diversities, three species diversity indices and 14 dasometric variables but patterns 289 related to the geographical coordinates (i.e., latitude and longitude) were not found.

290

291

292

293

294

295

296

297

298

299

300

301

302

303

304

305

306

307

308

309

310

311

\section{Principal component analysis and logistic regression}

Eight uncorrelated variables (Mmin, Gsdd5, $\mathrm{v}_{\mathrm{sp}, 0}, \mathrm{Dg}_{\text {tot }}, \mathrm{NO}_{3}, \mathrm{Zn}, \% \mathrm{Mg}$ and $\mathrm{H}_{\text {max,tot }}$ ) from the 14 P. chihuahuana populations were selected for logistic regression analysis. This selection was based on a PCA (Fig. 3). The logistic regression analysis revealed that the Mmin clearly separated the southern from northern populations (Fig. 4A).

However, Mmin is a variable from the PCA factor group 1 (F1), and was strongly correlated with other eight F1 variables with high factorial loads (Long, Map, Gsp, Mtcm, Mmax, Mmindd0, Smrp, and \%Sand), indicating that these eight variables were also important for characterizing and separating the two clusters. Since these eight variables characterized to $100 \%$ the two clusters, we considered that the binominal logit models were no longer needed.

Moreover, the probability $(p)$ of being a northern population is higher if the sand proportion in the soil $(\%$ Sand $)$ was significant lower $(\mathrm{SE}$ of Intercept $=10.178, p=0.0242, \mathrm{SE}$ of $\%$ Sand $=$ 0.146, $p=0.0199$, residual deviance: 9.467 on 12 degrees of freedom, AIC: 13.467) (Fig. 4B). The model is:

$$
P=\frac{1}{1+e^{-0.3396 \text { Sand }+22.937}}
$$

Significant differences in genetic variables and species diversity between southern and northern populations and locations were not found, although higher $\mathrm{v}_{2}$ and DW were more probable in the northern populations.

According to the most important variables for the separation of the two clusters (Tables S1-S8) the logistic regression analysis of the $P$. chihuahuana populations revealed that the southern locations were characterized by more abundant precipitation in the summer, in the growing season and in the annual average in comparison to the northern locations. The southern populations also showed higher mean temperature in the coldest month, lower mean maximum 
312 temperature in the warmest month and less degree-days below $0{ }^{\circ} \mathrm{C}$ (based on mean minimum

313 monthly temperature).

\section{Ordinary kriging analysis and Spearman correlations}

315 There was not a genetic diversity gradient from the northern to the southern cluster. The 316 best kriging model was found for $v_{2}$ using the exponential model $\left(r_{k}=0.842\right.$; URMSE $\left.=0.019\right)$

317 (Fig. 5A). On the other hand, the goodness-of-fit of both the PLOY and DW models was poorer, 318 respectively $\left(r_{k}=0.633\right.$, URMSE $=0.063$ and $r_{k}=0.4165$, URMSE $\left.=0.123\right)$. The prediction and 319 standard error surface maps of $v_{2}$ are shown in Fig. 5B.

320 After Bonferroni correction, the mean genetic diversity $v_{2}$ of $P$. chihahuana was 321 significantly correlated with the mean temperature in the warmest month $\left({ }^{\circ} \mathrm{C}\right)(\mathrm{Mtwm})(p=$ 322 0.0002) (Table 6, Figure 6). Genetic diversity of $P$. chihuahuana calculated with putatively 323 adaptive AFLP markers was not statistically significantly correlated with any environmental 324 factor. Finally, no significant positive correlations were observed between any of the three genetic diversity indices and population size. The negative association between genetic diversity and geographical distance to the next population was not significant $\left(\mathrm{r}_{\mathrm{s}}\left(\mathrm{v}_{2} \mathrm{x} \mathrm{d}_{\min }\right)=-0.46, p=\right.$ $\left.0.09 ; \mathrm{r}_{\mathrm{s}}\left(\mathrm{PLOY} \times \mathrm{d}_{\min }\right)=-0.42, p=0.13 ; \mathrm{r}_{\mathrm{s}}\left(\mathrm{DW} \times \mathrm{d}_{\min }\right)=-0.24, p=0.41\right)$.

\section{Discussion}

Our main findings show that the southern and northern $P$. chihuahuana populations are characterized by different climate conditions. Seven climate variables, besides the geographical longitude and the sand proportion in soil (Fig. 3, Tables S1-S8) were identified as important and relevant for separating the two groups and explained almost $100 \%$ of the variability. However, the most important climate variable to differentiate the $P$. chihuahuana populations was Mmin, which is strongly correlated with Long, Map, Gsp, Mtcm, Mmax, Mmindd0, Smrp, and \%Sand. These findings are consistent with other studies, since several authors have reported that the distribution of species and populations depends on both climate and soil (e.g. Condit et al., 2013; Toledo et al., 2012; John et al., 2007).

The southern locations were characterized by more oceanic climate probably caused by absence of the mountain barrier of Baja California peninsula, northwestern Mexico. The maximum 
341 in the southern ones. However, the future climate conditions, i.e. likely even higher temperatures

342 and less precipitation may strongly restrict biomass production and the vitality of the most 343 northern populations. This was observed by Ledig et al. (2010) who identified the most northern

344 locations as the first group that may be threatened with extinction in some climate change 345 projections.

346 The genetic diversity in P. chihuahuana is mostly moderate compared with other Picea species 347 (Simental-Rodríguez et al., 2014; Wehenkel \& Sáenz-Romero, 2012). The genetic diversity 348 across all the AFLPs studied was not an important variable for separating the two clusters of $P$. 349 chihuahuana populations (Fig. 5). However, it was significantly correlated with Mtwm (Table 6 350 and Fig. 6), where sites with warmer Mtwm harbor populations with larger genetic diversity. The 351 most northern populations in the municipality of Bocoyna, Chihuahua were the sites with the 352 highest Mtwm and aridity (lower precipitation values) (Tables S1-S8).

353 The genetic diversity among the putatively adaptive AFLPs was not significantly related to other 354 variables. The relationships observed were probably not determined by adaptation, but by differences in the degree of isolation, which could influence gene flow and genetic drift (Ledig et al. 1997; Jaramillo-Correa et al., 2006; Quiñones-Pérez, Sáenz-Romero \& Wehenkel, 2014). In comparison to the center and south, the most northern populations (municipality of Bocoyna) were much closer (about $3 \mathrm{~km}$ of mean distance from each other). After considering together the 11 documented populations in the Municipality of Bocoyna, Chih., the separation distances were: minimum $0.1 \mathrm{~km}$, mean $13 \mathrm{~km}$ and maximum $25 \mathrm{~km}$ to each other. The fact that northern populations are located closer to each other may directly lead to a greater genetic exchange and a lower tendency for genetic drift and inbreeding and thus, to a higher level of genetic diversity (Hamrick, Godt \& Sherman-Broyles, 1992; Ledig et al., 1997). This assumption was confirmed by the negative, but not significant association between genetic diversity and geographical distance between neighbor populations detected in our study.

Jaramillo-Correa et al. (2006) also found that the diversity of cpDNA in P. chihuahuana decreased from northern to southern areas (with the highest to the lowest Mtwm, respectively). These authors assumed that genetic drift, rather than selection, was the main factor determining the population diversity in the Chihuahua spruce. Moreover, the observations of Ledig et al. 
370 (1997), based on isozyme analysis, also suggest the importance of drift and inbreeding in the

371 recent evolution of this tree species.

372 Measurement of these environmental variables may be useful to identifying suitable and similar

373 sites to those where the original stands are still growing, which may help to improve

374 reforestation success. However, it will be important to specifically consider local micro climatic

375 conditions that are not easy modelled with simple macro climate models (Aguilar-Soto et al.,

376 2015), but can be recorded at new local weather stations within the populations.

\section{Conclusions}

378 Our findings have three important practical implications in relation to ex situ conservation: First, at least two different groups (clusters of natural populations) of P. chihuahuana probably exist

380

381

382

383

384

385

386

387

388

389

390

391

392

393

394 (according to the results of our cluster analysis), as local adaptation that may take place because of the different climate and soil conditions. Climate has been recognized as the main driver of adaptation (Vander, Bischoff \& Smith, 2010). These different groups are also designated by genetic differences between the southern and northern populations (Ledig et al., 1997; JaramilloCorrea et al., 2006; Quiñones-Pérez, Sáenz-Romero \& Wehenkel, 2014), even if only most likely using neutral markers. Therefore, future reforestation programs should only be established with seed sources from the same geographical group. Second, there are not relevant climate environmental and genetic differences within each of the two clusters; thus, seed from different populations of the same group could be mixed for improvement of genetic diversity levels. Third and finally, this study revealed the special macro-climate and soil conditions needed in the locations where $P$. chihuahuana is growing. Therefore, knowledge of these special conditions may be very helpful for find adequate reforestation locations in Mexico and other countries, which should have similar characteristics to the original sites.

\section{Acknowledgements}

We are grateful to the two anonymous reviewers for their careful reading of the manuscript and their suggestions to improve it.

\section{References}

Aguilar-Soto V, Melgoza-Castillo A, Villarreal-Guerrero F, Wehenkel CA, Pinedo-Alvarez C. 2015. Modeling the potential distribution of Picea chihuahuana Martínez, an endangered 
400

401

402

403

404

405

406

407

408

409

410

411

412

413

414

415

416

417

418

419

420

421

422

423

424

425

426

427

428

429

430

431

432

433

434

435

436

437

species at the Sierra Madre Occidental, Mexico. Forests 6:692-707. DOI: 10.3390/f6030692.

Assmann E.1970. The principles of Forest Yield Study. Oxford: Pergamon Press. 506 pp.

Ávila-Flores IJ, Hernández-Díaz JC, González-Elizondo MS, Prieto-Ruíz JÁ, Wehenkel CA. 2016. Degree of hybridization in seed stands of Pinus engelmannii Carr. in the Sierra Madre Occidental, Durango, Mexico. PloS ONE 11:e0152651. DOI: 10.1371/journal.pone.0152651.

Baker AS. 1967. Colorimetric determination of nitrate in soil and plant extracts with brucine. Journal of Agricultural and Food Chemistry 15:802-806.

Batista APB, Mello JMD, Raimundo MR, Scolforo HF, Reis AAD, Scolforo JRS. 2016. Species richness and diversity in shrub savanna using ordinary kriging. Pesquisa Agropecuária Brasileira 51:958-966. DOI: http://dx.doi.org/10.1590/S0100-204X2016000800008.

Bodenhofer U, Kothmeier A, Hochreiter S. 2011. APCluster: an R package for affinity propagation clustering. Bioinformatics 27:2463-2464. DOI: https://doi.org/10.1093/bioinformatics/btr406

Castellanos JZ, Uvalle-Bueno JX, Aguilar-Santelises A. 1999. Memoria del curso sobre interpretación de análisis de suelos, agua agrículas, plantas y ECP. México: Instituto para la Innovación Tecnológica en la Agricultura.

Condit R, Engelbrecht BM, Pino D, Pérez R, Turner BL. 2013. Species distributions in response to individual soil nutrients and seasonal drought across a community of tropical trees. Proceedings of the National Academy of Sciences 110:5064-5068. DOI: 10.1073/pnas.1218042110.

Farjon A, Page CN, Schellevis N. 1993. A preliminary world list of threatened conifer taxa. Biodiversity and Conservation 2:304-326. DOI: 10.1007/BF00056675.

Fisher RA. 1936. The use of multiple measurements in taxonomic problems. Annals of Eugenics 7:179-188. DOI: 10.1111/j.1469-1809.1936.tb02137.x.

Frankham R, Ballou JD, Briscoe DA. 2002. Introduction to conservation genetics. Cambridge: Cambridge University Press.

Frey BJ, Dueck D. 2007. Clustering by passing messages between data points. Science 315:972976. DOI: $10.1126 /$ science. 1136800 .

Gordon AG. 1968. Ecology of Picea chihuahuana Martínez. Ecology 49:5. DOI: $10.2307 / 1936540$.

Gregorius HR. 1978. The concept of genetic diversity and its formal relationship to heterozygosity and genetic distance. Mathematical Biosciences 41:253-432. DOI: 10.1016/0025-5564(78)90040-8.

Hamrick JL, Godt MJW, Sherman-Broyles SL. 1992. Factors influencing levels of genetic diversity in woody plant species. In: Population genetics of forest trees. Netherlands: Springer. 95-124. 
438

439

440

441

442

443

444

445

446

447

448

449

450

451

452

453

454

455

456

457

458

459

460

461

462

463

464

465

466

467

468

469

470

471

472

473

474

475

Hartigan, JA, Wong MA. 1979. Algorithm AS 136: A k-means clustering algorithm. Applied statistics. Journal of the Royal Statistical Society Series C (Applied Statistics) 28:100108. DOI: $10.2307 / 2346830$.

Hauke J, Kossowski T. 2011. Comparison of values of Pearson's and Spearman's correlation coefficients on the same sets of data. Quaestiones geographicae 30:87-93. DOI: 10.2478/v10117-011-0021-1.

Herbert VF. 1992. Prácticas de relaciones agua-suelo-planta-atmósfera. Mexico: Universidad Autónoma de Chapingo.

Hiemstra PH, Pebesma EJ, Twenhöfel CJ, Heuvelink GB. 2009. Real-time automatic interpolation of ambient gamma dose rates from the Dutch radioactivity monitoring network. Computers \& Geosciences 35:1711-1721. DOI: https://doi.org/10.1016/j.cageo.2008.10.011.

Hochberg Y. 1988. A sharper Bonferroni procedure for multiple tests of significance. Biometrika 75:800-802. DOI: https://doi.org/10.1093/biomet/75.4.800.

Hosmer JDW, Lemeshow S, Sturdivant RX. 2013. Applied logistic regression. John Wiley \& Sons.

Hughes AR, Inouye BD, Johnson MT, Underwood N, Vellend M. 2008. Ecological consequences of genetic diversity. Ecology Letters 11:609-623. DOI: 10.1111/j.14610248.2008.01179.x.

Hutchinson ME. 1991. Continent-wide data assimilation using thin plate smoothing splines. In: Jasper ED, ed. Data assimilation systems. Melbourne: Meteorology. 104-113.

Hutchinson ME. 2004. Anusplin version 4.3. Centre for Resource and Environmental Studies. The Australian National University, Canberra, Australia.

IUCN Red List of Threatened Species. 2013. Available at: http://www.iucnredlist.org/details/32479/0 (accessed 23 November 2016).

Jaramillo-Correa JP, Beaulieu J, Ledig FT, Bousquet J. 2006. Decoupled mitochondrial and chloroplast DNA population structure reveals holocene collapse and population isolation in a threatened Mexican-endemic conifer. Molecular Ecology 15:2787-2800. DOI: 10.1111/j.1365-294X.2006.02974.X.

John R, Dalling JW, Harms KE, Yavitt JB, Stallard RF, Mirabello M, Foster RB. 2007. Soil nutrients influence spatial distributions of tropical tree species. Proceedings of the National Academy of Sciences 104:864-869. DOI: 10.1073/pnas.0604666104

Jump AS, Hunt JM, Martínez-Izquierdo JA, Penuelas J. 2006. Natural selection and climate change: temperature-linked spatial and temporal trends in gene frequency in Fagus sylvatica. Molecular Ecology 15:3469-3480. DOI: 10.1111/j.1365-294X.2006.03027.x.

Ledig FT, Mápula-Larreta M, Bermejo-Velázquez B, Reyes-Hernández V, Flores-López C, Capó-Arteaga MA. 2000. Locations of endangered spruce populations in Mexico and the demography of Picea chihuahuana. Madroño 71-88. 
476

477

478

479

480

481

482

483

484

485

486

487

488

489

490

491

492

493

494

495

496

497

498

499

500

501

502

503

504

505

506

507

508

509

510

511

512

513

514
Ledig FT, Rehfeldt GE, Sáenz-Romero C, Flores-López C. 2010. Projections of suitable habitat for rare species under global warming scenarios. American Journal of Botany 97:970987. DOI: 10.3732/ajb.0900329.

Ledig, FT, Jacob-Cervantes V, Hodgskiss PD, Eguiluz-Piedra T. 1997. Recent evolution and divergence among populations of a rare Mexican endemic, Chihuahua spruce, following Holocene climatic warming. Evolution 51:1815-1827. DOI: 10.2307/2411004.

Legendre P, Legendre L. 1998. Numerical Ecology. Amsterdam: Elsevier Science B.V.

León AR, Aguilar AS. 1987. Materia orgánica. In: Aguilar A, Etchevers JD, Castellanos JZ (eds.) Análisis químico para evaluar la fertilidad del suelo. Chapingo, Estado de México: Publicación especial No. 1. Sociedad Mexicana de la Ciencia del Suelo. 85-91.

Mendoza-Maya E, Espino-Espino J, Quiñones-Pérez CZ, Flores-López C, Wehenkel C, VargasHernández JJ, Sáenz-Romero C. 2015. Proposal for conservation of three endangered species of Mexican spruce. Revista Fitotecnia 38:235-247.

Meudt HM, Clarke AC. 2007. Almost forgotten or latest practice? AFLP applications, analyses and advances. Trends in Plant Science 12:106-117. DOI: http://dx.doi.org/10.1016/j.tplants.2007.02.001.

Mualem Y. 1976. A new model for predicting the hydraulic conductivity of unsaturated porous media. Water resources research 12:513-522. DOI: 10.1029/WR012i003p00513.

Narváez FR. 1984. Contribution to Knowledge Ecology Picea chihuahuana. Professional Thesis (Biology), Universidad Autonoma de Nuevo Leon School of Biological Sciences, Mexico.

Nunes VL, Beaumont MA, Butlin RK, Paulo OS 2012. Challenges and pitfalls in the characterization of anonymous outlier AFLP markers in non-model species: lessons from an ocellated lizard genome scan. Heredity 109: 340-348.

Olsen SR, Cole CV, Watanabe FS, Dean LA. 1954. Estimation of available phosphorus in soil by extraction with NaHCO3, USDA Ciraza (Quoted from, Method of soil Analysis, CA Black 2nd ed.) 1165. Wisconsin, USA: Am. Soc. Agron., Inc. Madison.

Quiñones-Pérez CZ, Sáenz-Romero C, Wehenkel C. 2014. Genetic diversity and conservation of Picea chihuahana Martinez: A review. African Journal of Biotechnology 13:2786-2795.

Quiñones-Pérez CZ, Simental-Rodriguez SL, Saenz-Romero C, Jaramillo-Correa JP, Wehenkel C. 2014. Spatial genetic structure in the very rare and species-rich Picea chihuahuana tree community (Mexico). Silvae Genetica 63:149-159.

Peakall R. and Smouse PE. 2006. GenAlEx 6.5: genetic analysis in Excel. Population genetic software for teaching and research - an update. Bioinformatics 28:2537-2539. DOI: 10.1111/j.1471-8286.2005.01155.x.

Pearson K. 1901. On Lines and Planes of Closest Fit to Systems of Points in Space. Philosophical Magazine 2:559-572. DOI: 10.1126/science.1136800.

Pebesma EJ, Bivand RS. 2005. Classes and methods for spatial data in R. R News 5. Available at: https://cran.r-project.org/doc/Rnews/ (accessed 1 April 2017). 
515

516

517

518

519

520

521

522

523

524

525

526

527

528

529

530

531

532

533

534

535

536

537

538

539

540

541

542

543

544

545

546

547

548

549

550

551

552

553

R Core Team (2015). R: A language and environment for statistical computing. R Foundation for Statistical Computing, Vienna, Austria. Available at: http://www.R-project.org/ (accessed 7 June 2016).

Reed DH, Frankham R. 2003. Correlation between fitness and genetic diversity. Conservation Biology 17:230-237. DOI: 10.1046/j.1523-1739.2003.01236.x.

Rehfeldt GE. 2006. A spline model of climate for the Western United States. Gen Tech Rep. RMRS-GTR-165. U.S. Department of Agriculture, Forest Service, Rocky Mountain Research Station, Fort Collins, Colorado, USA.

Sáenz-Romero C, Rehfeldt GE, Crookston NL, Duval P, St-Amant R, Beaulieu J, Richardson BA. 2010. Spline models of contemporary, 2030, 2060 and 2090 climates for Mexico and their use in understanding climate-change impacts on the vegetation. Climatic Change 102:595-623. DOI: 10.1007/s10584-009-9753-5.

Schönswetter P, Tribsch A. 2005. Vicariance and dispersal in the alpine perennial Bupleurum stellatum L. (Apiaceae). Taxon 54:725-732.

SEMARNAT (Secretaría de Medio Ambiente y Recursos Naturales), 2010. NOM-059SEMARNAT-2010. Available at: http://www.profepa.gob.mx/innovaportal/file/435/1/NOM_059 SEMARNAT_2010.pdf (accessed 23 November 2016).

Simental-Rodríguez SL, Quiñones-Pérez CZ, Moya D, Hernández-Tecles E, López-Sánchez CA, Wehenkel C. 2014. The Relationship between Species Diversity and Genetic Structure in the Rare Picea chihuahuana Tree Species Community, Mexico. PloS One 9:e111623.

Thomas P, Farjon A. 2013. Picea chihuahuana. The IUCN Red List of Threatened Species 2013: e.T32479A2820455. Available at: http://dx.doi.org/10.2305/IUCN.UK.20131.RLTS.T32479A2820455 (accessed 13 January 2017).

Toledo M, Peña-Claros M, Bongers F, Alarcón A, Balcázar J, Chuviña J, Poorter L. 2012. Distribution patterns of tropical woody species in response to climatic and edaphic gradients. Journal of Ecology 100: 253-263. DOI: 10.1111/j.1365-2745.2011.01890.x

Vander MK, Bischoff A, Smith B. 2010. A question of origin: where and how to collect seed for ecological restoration. Basic and Applied Ecology 11:300-311. DOI: http://dx.doi.org/10.1016/j.baae.2009.09.002.

Vázquez AA, Bautista N. 1993. Guía para interpretar el análisis químico de suelo y agua. Departamento de Suelos. Universidad. Autónoma de Chapingo. México.

Venables WN, Ripley BD. 2002. Modern Applied Statistics with S-Plus. Fourth Edition. New York: Springer.

Vos P, Hogers R, Bleeker M, Reijans M, Van de Lee T, Hornes M, Frijters A, Pot J, Pelemn J, Kuiper M, Zabea M.1995. AFLP: a new technique for DNA fingerprinting. Nucleic Acids Research 23:4407-4414. DOI: 10.1093/nar/23.21.4407.

Wehenkel C, Corral-Rivas JJ, Castellanos-Bocaz HA. 2010. Is there selection by species diversity in Picea abies L.? Plant Ecology 208:47-54. 
554 Wehenkel C, Brazão-Protázio JM, Carrillo-Parra A, Martínez-Guerrero JH, Crecente-Campo F.

555

556

557

558

559

560

561

562

563

564

565

566

567

568

569

570 Tables

571 Table 1. Locations of the 14 Picea chihuahuana populations under study.

\begin{tabular}{|c|c|c|c|c|c|c|c|c|c|}
\hline $\begin{array}{l}\text { Geographical } \\
\text { Group }\end{array}$ & Code & Property & Municipality & Location & $\begin{array}{c}\text { Population } \\
\text { Size (T)* }\end{array}$ & $\begin{array}{c}\text { Sample } \\
\text { size }\end{array}$ & $\begin{array}{c}\text { Latitude } \\
\text { N }\end{array}$ & $\begin{array}{c}\text { Longitude } \\
\text { W }\end{array}$ & $\begin{array}{c}\text { Altitude } \\
\text { m }\end{array}$ \\
\hline \multirow{6}{*}{ 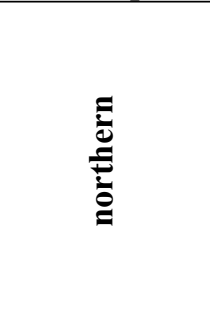 } & $\mathrm{TN}$ & El Ranchito & Bocoyna & La Tinaja & 99 & 50 & $27^{\circ} 57^{\prime} 27^{\prime \prime}$ & $107^{\circ} 46^{\prime} 13^{\prime \prime}$ & 2,380 \\
\hline & $\mathrm{RC}$ & El Ranchito & Bocoyna & El Ranchito & 217 & 51 & $27^{\circ} 57^{\prime} 20^{\prime \prime}$ & $107^{\circ} 45^{\prime} 12^{\prime \prime}$ & 2,414 \\
\hline & $\mathrm{CV}$ & El Ranchito & Bocoyna & El Cuervo & 140 & 50 & $27^{\circ} 57^{\prime} 01^{\prime \prime}$ & $107^{\circ} 46^{\prime} 18^{\prime \prime}$ & 2,500 \\
\hline & TY & Los Volcanes & Bocoyna & Talayote & 291 & 53 & $27^{\circ} 55^{\prime} 03^{\prime \prime}$ & $107^{\circ} 49^{\prime} 01^{\prime \prime}$ & 2,355 \\
\hline & TR & El Ranchito & Bocoyna & Las Troja & 834 & 51 & $27^{\circ} 54^{\prime} 27^{\prime \prime}$ & $107^{\circ} 45^{\prime} 17^{\prime \prime}$ & 2,395 \\
\hline & VN & San Javier & Bocoyna & El Venado & 1,785 & 57 & $27^{\circ} 45^{\prime} 41^{\prime \prime}$ & $107^{\circ} 41^{\prime} 33^{\prime \prime}$ & 2,311 \\
\hline \multirow{4}{*}{$\bar{\Xi}$} & LQ & $\begin{array}{c}\text { El Caldillo y } \\
\text { su anexo El } \\
\text { Vergel }\end{array}$ & Balleza & La Quebrada & 877 & 50 & $26^{\circ} 28^{\prime} 13^{\prime \prime}$ & $106^{\circ} 21^{\prime} 51^{\prime \prime}$ & 2,730 \\
\hline & PPR & Chiqueros & Guanaceví & $\begin{array}{c}\text { Paraje Piedra } \\
\text { Rayada }\end{array}$ & 3,564 & 42 & $26^{\circ} 09^{\prime} 15^{\prime \prime}$ & $106^{\circ} 24^{\prime} 17^{\prime \prime}$ & 2,600 \\
\hline & QD & Chiqueros & Guanaceví & $\begin{array}{l}\text { Quebrada de } \\
\text { los Duran }\end{array}$ & 2,628 & 49 & $26^{\circ} 08^{\prime} 48^{\prime \prime}$ & $106^{\circ} 22^{\prime} 53^{\prime \prime}$ & 2,570 \\
\hline & $\mathrm{CB}$ & $\begin{array}{l}\text { Private } \\
\text { property }\end{array}$ & Canelas & Cebollitas & 172 & 51 & $25^{\circ} 05^{\prime} 55^{\prime \prime}$ & $106^{\circ} 26^{\prime} 27^{\prime \prime}$ & 2,450 \\
\hline \multirow{4}{*}{ } & SJ & $\begin{array}{l}\text { San José de } \\
\text { las Causas }\end{array}$ & San Dimas & $\begin{array}{l}\text { San José de } \\
\text { las Causas }\end{array}$ & 21 & 51 & $24^{\circ} 01^{\prime} 07^{\prime \prime}$ & $105^{\circ} 47^{\prime} 56^{\prime \prime}$ & 2,480 \\
\hline & SB & El Brillante & Pueblo Nuevo & Santa Bárbara & 148 & 48 & $23^{\circ} 39^{\prime} 44^{\prime \prime}$ & $105^{\circ} 26^{\prime} 20^{\prime \prime}$ & 2,725 \\
\hline & $\mathrm{ACH}$ & $\begin{array}{l}\text { Santa Maria } \\
\text { Magdalena de } \\
\text { Taxicaringa }\end{array}$ & Mezquital & $\begin{array}{l}\text { Arroyo del } \\
\text { Chino }\end{array}$ & 46 & 17 & $23^{\circ} 21^{\prime} 05^{\prime \prime}$ & $104^{\circ} 43^{\prime} 05^{\prime \prime}$ & 2,600 \\
\hline & LP & $\begin{array}{c}\text { Santa Maria } \\
\text { Magdalena de }\end{array}$ & Mezquital & La pista & 919 & 49 & $23^{\circ} 19^{\prime} 52^{\prime \prime}$ & $104^{\circ} 45^{\prime} 00^{\prime \prime}$ & 2,685 \\
\hline
\end{tabular}


Taxicaringa

$572 *$ taken from Table 6 of Ledig et al. (2000)

573

574

575

576

577

578

579

580

581

582

583 Table 2. Descriptive statistics for the 22 physiographic and climatic variables, SD $=$ standard 584 deviation, $\mathrm{n}=14$.

\begin{tabular}{|c|c|c|c|c|c|}
\hline & Variable Climatic & Minimum & Maximum & Mean & SD \\
\hline Long & Longitude & -107.817 & -104.718 & -106.703 & 1.064 \\
\hline Lat & Latitude & 23.30 & 27.90 & 26.12 & 1.88 \\
\hline Elev & Elevation (m) & 2,311 & 2,730 & 2,509 & 132 \\
\hline Mat & Mean annual temperature $\left({ }^{\circ} \mathrm{C}\right)$ & 9.70 & 11.90 & 10.80 & 0.50 \\
\hline Map & Mean annual precipitation $(\mathrm{mm})$ & 700 & 1,350 & 905.9 & 218.9 \\
\hline Gsp & $\begin{array}{l}\text { Growing season precipitation, April to } \\
\text { September }(\mathrm{mm})\end{array}$ & 520 & 941 & 658.0 & 150.5 \\
\hline Mtcm & $\begin{array}{l}\text { Mean temperature in the coldest month } \\
\left({ }^{\circ} \mathrm{C}\right)\end{array}$ & 3.80 & 7.30 & 5.00 & 1.00 \\
\hline Mmin & $\begin{array}{l}\text { Mean minimum temperature in the } \\
\text { coldest month }\left({ }^{\circ} \mathrm{C}\right)\end{array}$ & -5.6 & -1.3 & -4.2 & 1.4 \\
\hline Mtwm & $\begin{array}{l}\text { Mean temperature in the warmest month } \\
\left({ }^{\circ} \mathrm{C}\right)\end{array}$ & 13.80 & 17.20 & 15.80 & 1.08 \\
\hline Mmax & $\begin{array}{l}\text { Mean maximum temperature in the } \\
\text { warmest month }\left({ }^{\circ} \mathrm{C}\right)\end{array}$ & 21.70 & 26.60 & 24.80 & 1.40 \\
\hline Sday & $\begin{array}{l}\text { Julian date of the last freezing date of } \\
\text { spring }\end{array}$ & 1260 & 163.00 & 151.00 & 10.0 \\
\hline Fday & $\begin{array}{l}\text { Julian date of the first freezing date of } \\
\text { autumn }\end{array}$ & 266 & 295 & 281 & 9 \\
\hline Ffp & Length of the frost-free period (days) & 104 & 165 & 134 & 19 \\
\hline Dd5 & Degree-days above $5^{\circ} \mathrm{C}$ & 1,873 & 2,593 & 2,275 & 178 \\
\hline Gsdd5 & $\begin{array}{l}\text { Degree-days above } 5^{\circ} \mathrm{C} \text { in the frost-free } \\
\text { period }\end{array}$ & 974 & 1,679 & 1,323 & 220 \\
\hline D100 & $\begin{array}{l}\text { Julian date the sum of degree-days above } \\
5^{\circ} \mathrm{C} \text { reaches } 100\end{array}$ & 35 & 69 & 56 & 10 \\
\hline
\end{tabular}




\begin{tabular}{|c|c|c|c|c|c|}
\hline DD0 & $\begin{array}{l}\text { Degree-days below } 0{ }^{\circ} \mathrm{C} \text { (based on mean } \\
\text { monthly temperature) }\end{array}$ & 0 & 39 & 20 & 12 \\
\hline Mmindd0 & $\begin{array}{l}\text { Degree-days below } 0{ }^{\circ} \mathrm{C} \text { (based on mean } \\
\text { minimum monthly temperature) }\end{array}$ & 427 & 907 & 780 & 157 \\
\hline Smrpb & $\begin{array}{l}\text { Summer precipitation } \\
\text { balance: } \\
(\text { Jul+Aug+Sep)/(Apr+May+Jun) (mm) }\end{array}$ & 3.83 & 4.96 & 4.47 & 0.36 \\
\hline Smrsprpb & $\begin{array}{l}\text { Summer/Spring precipitation balance: } \\
(\text { Jul+Aug)/(Apr+May) }(\mathrm{mm})\end{array}$ & 10.53 & 14.48 & 12.49 & 1.00 \\
\hline Sprp & Spring precipitation (Apr+May) (mm) & 26 & 43 & 32 & 6 \\
\hline Smrp & $\begin{array}{l}\text { Summer precipitation } \\
(\mathrm{Jul}+\text { Aug })(\mathrm{mm})\end{array}$ & 316 & 544 & 396 & 81 \\
\hline Winp & $\begin{array}{l}\text { Winter precipitation } \\
(\mathrm{Nov}+\mathrm{Dec}+\mathrm{Jan}+\mathrm{Feb})(\mathrm{mm})\end{array}$ & 100 & 326 & 172 & 62 \\
\hline
\end{tabular}

585

586

587

588

589

590 Table 3. Descriptive statistics for the 27 soil variables, $\mathrm{SD}=$ standard deviation, $\mathrm{n}=14$.

\begin{tabular}{llcccc}
\hline & Soil variable & Minimum & Maximum & Mean & SD \\
\hline $\mathrm{EC}$ & Electric conductivity & 0.24 & 2.19 & 0.82 & 0.51 \\
& $(\mathrm{dS} / \mathrm{m})$ & & & & \\
$\mathrm{NO}_{3}$ & Nitrate (kg/ha) & 14.78 & 564.69 & 179.61 & 137.0 \\
$\mathrm{P}$ & Phosphorus (ppm) & 6.88 & 114.68 & 27.03 & 33.24 \\
$\mathrm{OM}$ & Organic material (\%) & 3.35 & 17.49 & 9.33 & 4.65 \\
\%CaCO & Calcium carbonate (\%) & 0.36 & 12.56 & 2.09 & 3.81 \\
3 & & & & 66.64 & 17.27 \\
\%Sat & Percent saturation (\%) & 29.00 & 92.00 & 64.26 & 7.64 \\
\%Sand & Sand (\%) & 51.26 & 75.26 & 23.99 & 5.64 \\
\%Silt & Silt (\%) & 15.28 & 33.28 & 11.75 & 3.02 \\
\%Clay & Clay (\%) & 7.46 & 17.46 & 0.89 & 0.13 \\
$\mathrm{Den}$ & Density (gr/cm $\left.{ }^{3}\right)$ & 0.70 & 1.07 & 5.80 & 0.52 \\
$\mathrm{pH}$ & pH & 4.80 & 7.22 & 5.97 & 0.22 \\
$\mathrm{Ca}$ & Calcium (ppm) & 5.44 & 6.15 & 4147.71 & 1086.96 \\
$\mathrm{Mg}$ & Magnesium (ppm) & 2340.00 & 6090.00 & 394.29 & 187.87 \\
$\mathrm{Na}$ & Sodium (ppm) & 144.00 & 942.00 & 77.54 & 34.27 \\
$\mathrm{~K}$ & Potassium (ppm) & 40.00 & 177.50 & 1697.18 & 1587.93 \\
$\mathrm{Fe}$ & Iron (ppm) & 191.00 & 6225.00 & 142.81 & 72.22 \\
$\mathrm{Zn}$ & Zinc (ppm) & 31.28 & 313.72 & 4.69 & 4.23 \\
$\mathrm{Mn}$ & Manganese (ppm) & 0.32 & 12.56 & 92.48 & 70.67 \\
$\mathrm{Cu}$ & Copper (ppm) & 16.64 & 266.20 & 0.45 & 0.26 \\
\%o.b. & Relative proportion of & 0.16 & 1.04 & & \\
\hline
\end{tabular}




\begin{tabular}{|c|c|c|c|c|c|}
\hline & $\begin{array}{l}\text { other bases in the cation } \\
\text { exchange capacity (\%) }\end{array}$ & & & & \\
\hline$\% \mathrm{Ca}$ & $\begin{array}{l}\text { Relative proportion of } \\
\mathrm{Ca} \text { in the cation } \\
\text { exchange capacity }(\%)\end{array}$ & 4.22 & 7.09 & 5.80 & 0.69 \\
\hline$\% \mathrm{Mg}$ & $\begin{array}{l}\text { Relative proportion of } \\
\mathrm{Mg} \text { in the cation } \\
\text { exchange capacity }(\%)\end{array}$ & 41.87 & 69.52 & 56.38 & 7.98 \\
\hline$\% \mathrm{~K}$ & $\begin{array}{l}\text { Relative proportion of } \\
\mathrm{K} \text { in the cation } \\
\text { exchange capacity }(\%)\end{array}$ & 5.29 & 15.06 & 8.69 & 2.62 \\
\hline$\% \mathrm{Na}$ & $\begin{array}{l}\text { Relative proportion of } \\
\mathrm{Na} \text { in the cation } \\
\text { exchange capacity }(\%)\end{array}$ & 2.36 & 21.95 & 10.01 & 6.04 \\
\hline$\% \mathrm{H}$ & $\begin{array}{l}\text { Relative proportion of } \\
\mathrm{H} \text { in the cation } \\
\text { exchange capacity }(\%)\end{array}$ & 0.34 & 1.76 & 0.93 & 0.33 \\
\hline CEC & $\begin{array}{l}\text { Cation exchange } \\
\text { capacity (meq / } 100 \mathrm{~g} \\
\text { soil) }\end{array}$ & 15.30 & 33.00 & 18.18 & 7.19 \\
\hline $\mathrm{HC}$ & $\begin{array}{l}\text { Hydraulic conductivity } \\
(\mathrm{cm} / \mathrm{h})\end{array}$ & 20.77 & 72.72 & 37.76 & 13.23 \\
\hline
\end{tabular}

591

592 Table 4. Descriptive statistics for 10 dasometric variables, four density variables and other 593 population variables. Dasometric variables including all trees with diameter at breast height $\geq$ $5947.5 \mathrm{~cm}, \mathrm{SD}=$ standard deviation, $\mathrm{n}=14$.

\begin{tabular}{|c|c|c|c|c|c|}
\hline & Dasometric variable & Minimum & Maximum & Mean & SD \\
\hline $\mathrm{Dg}$ & $\begin{array}{l}\text { Quadratic diameter at breast } \\
\text { height of } P \text {. chihuahuana per plot } \\
(\mathrm{cm})\end{array}$ & 0.00 & 40.10 & 30.32 & 10.56 \\
\hline DBH & $\begin{array}{l}\text { Diameter at breast height of } P \text {. } \\
\text { chihuahuana per plot }(\mathrm{cm})\end{array}$ & 0.00 & 35.50 & 26.55 & 9.08 \\
\hline $\mathrm{H}$ & $\begin{array}{l}\text { Height per plot (m) } P . \\
\text { chihuahuana }\end{array}$ & 0.00 & 21.10 & 15.86 & 5.25 \\
\hline $\mathrm{DBH}_{\max }$ & $\begin{array}{l}\text { Maximum diameter at breast } \\
\text { height of } P \text {. chihuahuana per plot } \\
(\mathrm{m})\end{array}$ & 0.00 & 78.00 & 55.21 & 20.47 \\
\hline $\mathrm{H}_{\max }$ & $\begin{array}{l}\text { Maximum height of } P . \\
\text { chihuahuana per plot (m) }\end{array}$ & 0.00 & 46.00 & 30.79 & 10.76 \\
\hline $\mathrm{Dg}_{\text {tot }}$ & $\begin{array}{l}\text { Total Quadratic diameter }(\mathrm{cm}) \\
\text { per plot }\end{array}$ & 22.10 & 37.30 & 28.01 & 3.83 \\
\hline $\mathrm{DBH}_{\text {tot }}$ & Total diameter $(\mathrm{cm})$ per plot & 17.9 & 32.90 & 23.93 & 3.5 \\
\hline $\mathrm{H}_{\mathrm{tot}}$ & Total height among (m) per plot & 9.7 & 17.90 & 14.11 & 2.14 \\
\hline $\mathrm{DBH}_{\text {max,tot }}$ & $\begin{array}{l}\text { Total maximum diameter at } \\
\text { breast height }(\mathrm{cm}) \text { per plot }\end{array}$ & 55.0 & 104.0 & 74.65 & 14.81 \\
\hline \multirow[t]{2}{*}{$\mathrm{H}_{\text {max,tot }}$} & $\begin{array}{l}\text { Total maximum height }(\mathrm{m}) \text { per } \\
\text { plot }\end{array}$ & 23.3 & 48.0 & 34.91 & 6.99 \\
\hline & Density variable & & & & \\
\hline $\mathrm{N}$ & $\begin{array}{l}\text { Number of individuals of } P . \\
\text { chihuahuana per plot }\end{array}$ & 0.00 & 140.0 & 76.29 & 41.79 \\
\hline G & Tree basal area of $P$. & 0.00 & 14.3 & 6.81 & 4.66 \\
\hline
\end{tabular}




\begin{tabular}{|c|c|c|c|c|c|}
\hline & chihuahuana per plot of $\left(\mathrm{m}^{2} / \mathrm{ha}\right)$ & & & & \\
\hline $\mathrm{N}_{\text {tot }}$ & $\begin{array}{l}\text { Total number of individuals per } \\
\text { plot }\end{array}$ & 152.00 & 736.00 & 369.71 & 139.36 \\
\hline \multirow[t]{2}{*}{$\mathrm{G}_{\text {tot }}$} & $\begin{array}{l}\text { Total tree basal area }\left(\mathrm{m}^{2} / \mathrm{ha}\right) \text { per } \\
\text { plot }\end{array}$ & 13.70 & 53.28 & 22.41 & 9.69 \\
\hline & Other population variables & & & & \\
\hline \multirow[t]{2}{*}{$\mathrm{d}_{\min }$} & $\begin{array}{l}\text { Geographical distance between } \\
\text { neighbor populations }(\mathrm{m})\end{array}$ & 62.90 & 77303.20 & 14737.00 & 24612.00 \\
\hline & $\begin{array}{l}\text { Population size (tree number per } \\
\text { population) }\end{array}$ & 21.00 & 3564.00 & 951.00 & 1264.00 \\
\hline
\end{tabular}

595

596

597

598

599

600

601

602 Table 5. Descriptive statistics for the nine genetic and species diversity variables, $\mathrm{SD}=$ standard 603 deviation, $\mathrm{n}=14$.

\begin{tabular}{|c|c|c|c|c|c|}
\hline \multicolumn{2}{|c|}{ Diversity variable } & \multirow{2}{*}{$\frac{\text { Minimum }}{1.43}$} & \multirow{2}{*}{$\frac{\text { Maximum }}{1.60}$} & \multirow{2}{*}{$\frac{\text { Mean }}{1.52}$} & \multirow{2}{*}{$\frac{\text { SD }}{0.06}$} \\
\hline $\mathrm{v}_{2}$ & Mean genetic diversity & & & & \\
\hline POLY & Percentage polymorphism & 0.80 & 1.02 & 0.94 & 0.07 \\
\hline DW & $\begin{array}{l}\text { Modified frequency-down- } \\
\text { weighted marker value }\end{array}$ & 0.08 & 0.12 & 0.1 & 0.01 \\
\hline $\mathrm{V}_{2}$ (adaptive AFLP) & $\begin{array}{l}\text { Mean genetic diversity per outlier } \\
\text { AFLP }\end{array}$ & 1.07 & 1.78 & 1.46 & 0.27 \\
\hline $\operatorname{POLY}_{\text {(adaptive AFLP) }}$ & $\begin{array}{l}\text { Percentage polymorphism per } \\
\text { outlier AFLP }\end{array}$ & 0.26 & 1.02 & 0.78 & 0.31 \\
\hline $\mathrm{DW}_{\text {(adaptive AFLP) }}$ & $\begin{array}{l}\text { Modified frequency-down- } \\
\text { weighted marker value per outlier } \\
\text { AFLP }\end{array}$ & 0.002 & 0.02 & 0.01 & 0.07 \\
\hline $\mathrm{v}_{\mathrm{sp}, 0}$ & Species richness & 4.00 & 9.00 & 6.17 & 1.49 \\
\hline $\mathrm{v}_{\mathrm{sp}, 2}$ & Effective number of tree species & 1.92 & 4.46 & 3.39 & 0.80 \\
\hline $\mathrm{v}_{\mathrm{sp}, \mathrm{inf}}$ & Number of prevalent tree species & 1.49 & 3.0 & 2.31 & 0.46 \\
\hline
\end{tabular}

604

605

606

607

608

609 
610

611

612

613

614

615

616

617

618

619

620

621

622

623

624

625

626 Table 6. Correlation between genetic diversity $\left(\mathrm{v}_{2}\right)$ and climate and soil variables in 14 Picea 627 chihuahuana populations.

\begin{tabular}{lcc}
\hline & Genetic diversity $\left(\mathrm{v}_{2}\right)$ \\
\hline Long & Spearman $\boldsymbol{r}$ & $\boldsymbol{P}$ \\
Mtwm & -0.74 & 0.0027 \\
Mmax & 0.83 & $0.0002^{*}$ \\
D100 & 0.70 & 0.0058 \\
DD0 & 0.68 & 0.0074 \\
Smrpb & 0.67 & 0.0088 \\
Smrsprpb & 0.69 & 0.0061 \\
Clay & -0.68 & 0.0076 \\
* = significant after Bonferroni correction
\end{tabular}

629

630

631 
632

633

634

635

636

637

638

639

640

641

642

643 Figures 


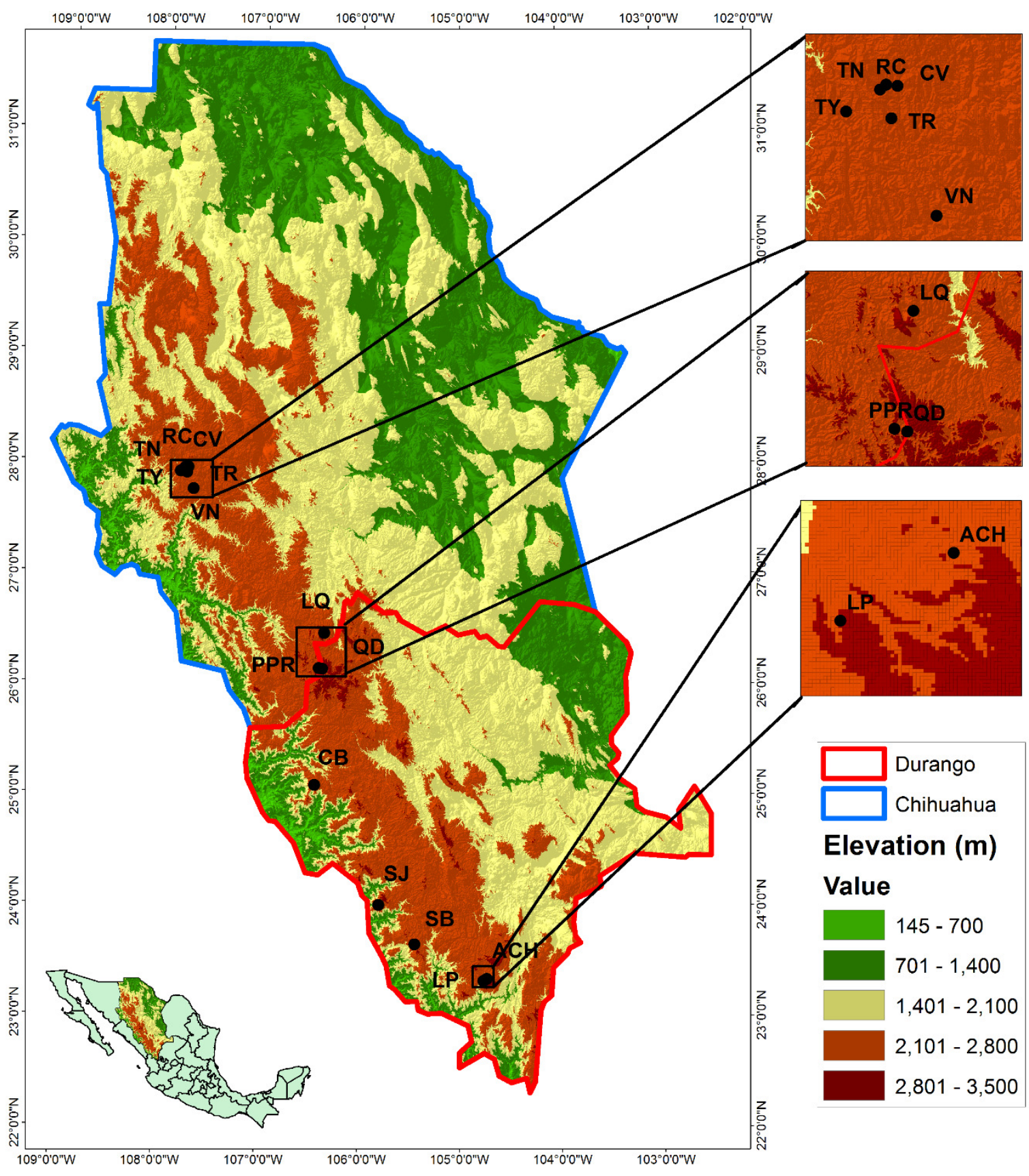

645 Figure 1. Locations of the studied populations: La Tinaja (TN), El Ranchito (RC), El Cuervo 646 (CV), Talayote (TY), Las Trojas (TR), El Venado (VN), La Quebrada (LQ), Paraje Piedra 647 Rayada (PPR), Quebrada de los Duran (QD), Cebollitas (CB), San José de las Causas (SJ), Santa 648 Bárbara (SB), Arroyo del Chino (ACH), La pista (LP). 
A

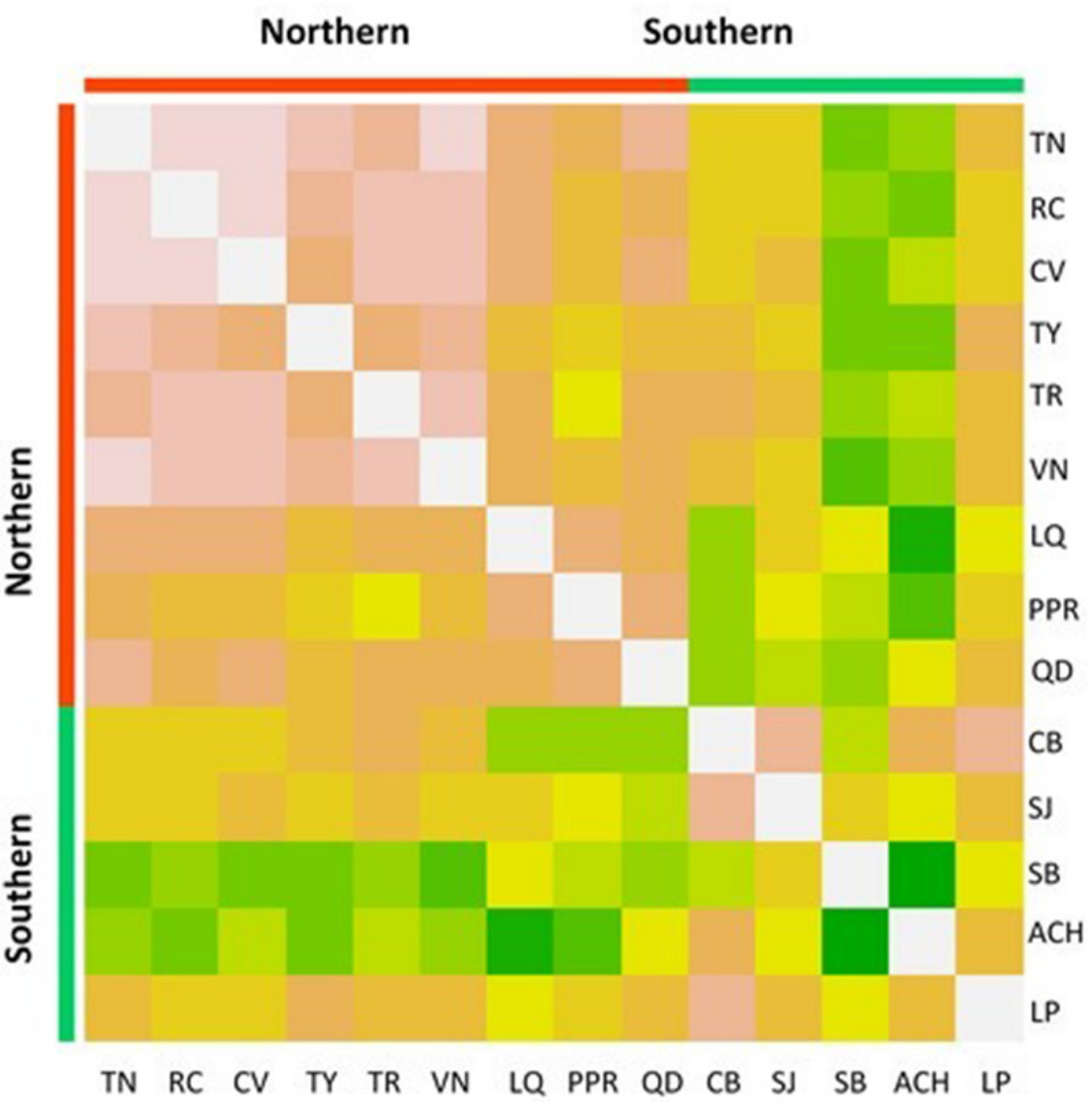

B

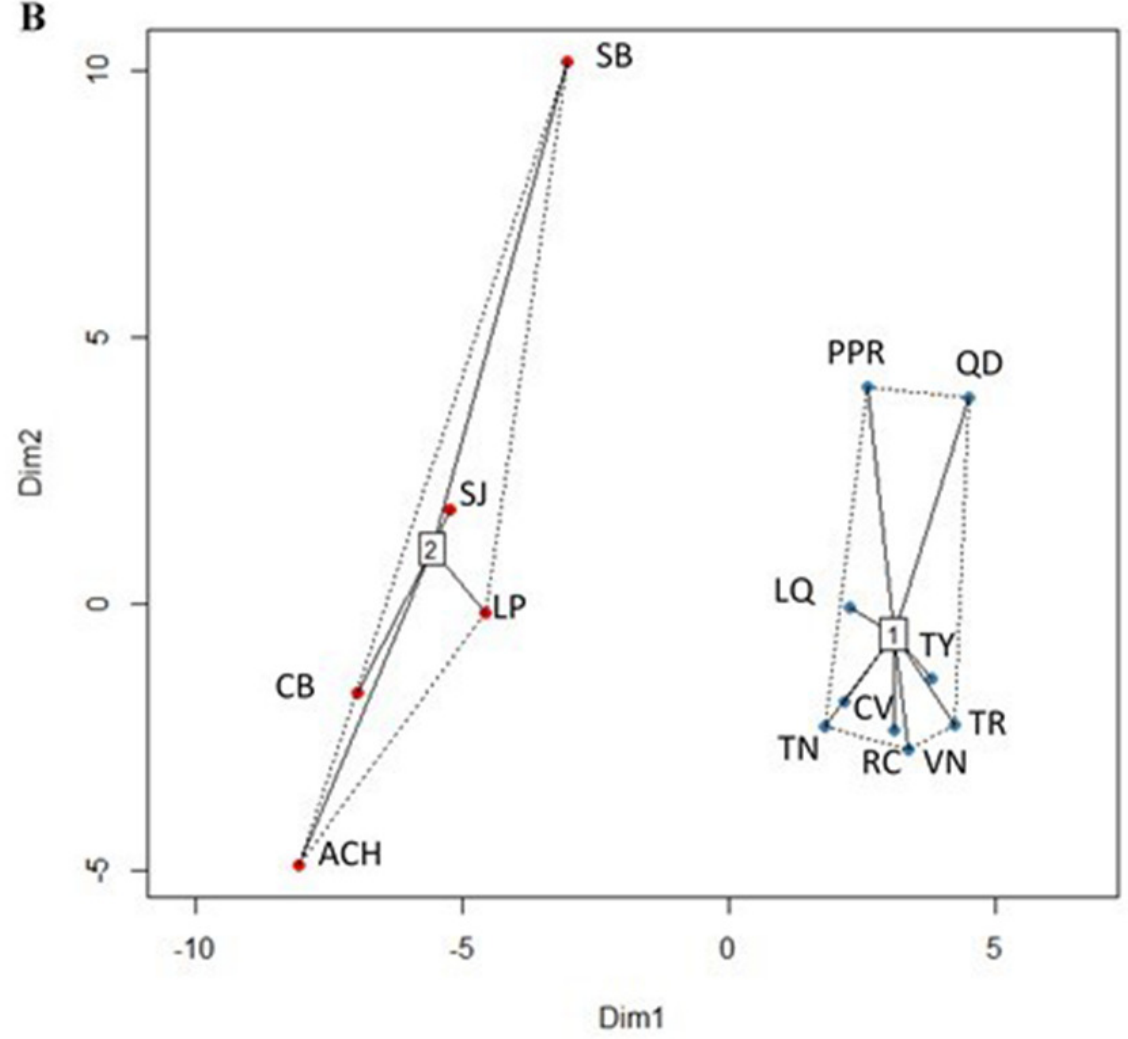


650 Figure 2 A and B. Clusters of Picea chihuahuana populations. A) Heat map to visualize the data 651 and to identify clusters of similar environmental conditions based on the Affinity Propagation

652 (AP) clustering, with the quantile $=0$. This analysis indicates that the 14 populations can be 653 subdivided into two clusters displayed as bright orange squares across the diagoal. Northern 654 populations: La Tinaja (TN), El Ranchito (RC), El Cuervo (CV), Talayote (TY), Las Trojas 655 (TR), El Venado (VN), La Quebrada (LQ), Paraje Piedra Rayada (PPR), Quebrada de los Duran 656 (QD). Southern populations: Cebollitas (CB), San José de las Causas (SJ), Santa Bárbara (SB), 657 Arroyo del Chino (ACH), La pista (LP) B) Clusters based on $k$-means. Cluster 1 includes the 658 nine northern populations; Cluster 2 includes the five most southern populations.

659

660

661

662

663

664

665

666

667

668

669

670

671

672

673

674

675

676

677

678

679

680 


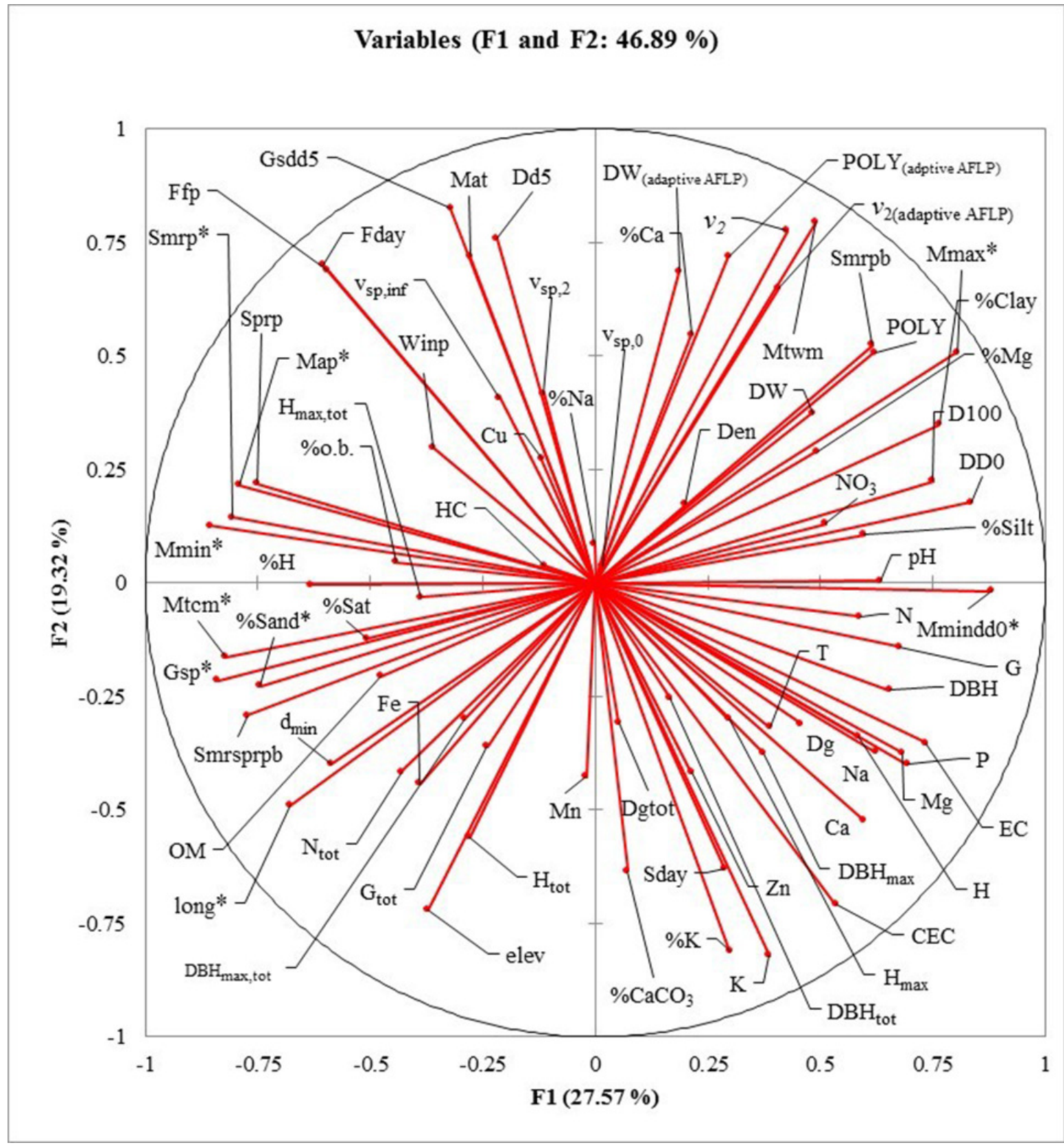

682 Figure 3. Principal Component Analysis (PCA) plot of variables under study in the factor groups 683 F1 and F2. The most important variables to separate the southern from northern populations of 684 Picea chihuahuana are asterisked. Abbreviations are defined in Tables 2 - 5.

685

686

687 


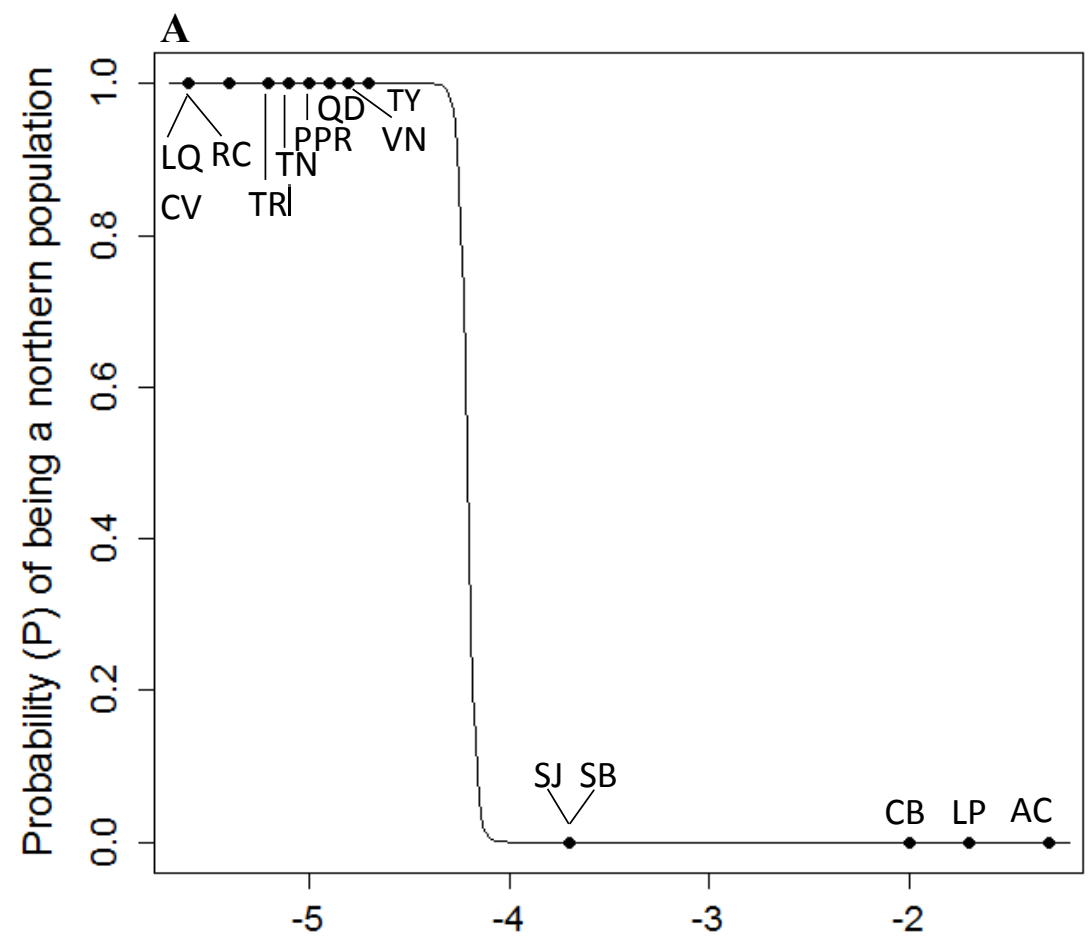

Mean minimum temperature in the coldest month $\left({ }^{\circ} \mathrm{C}\right)$

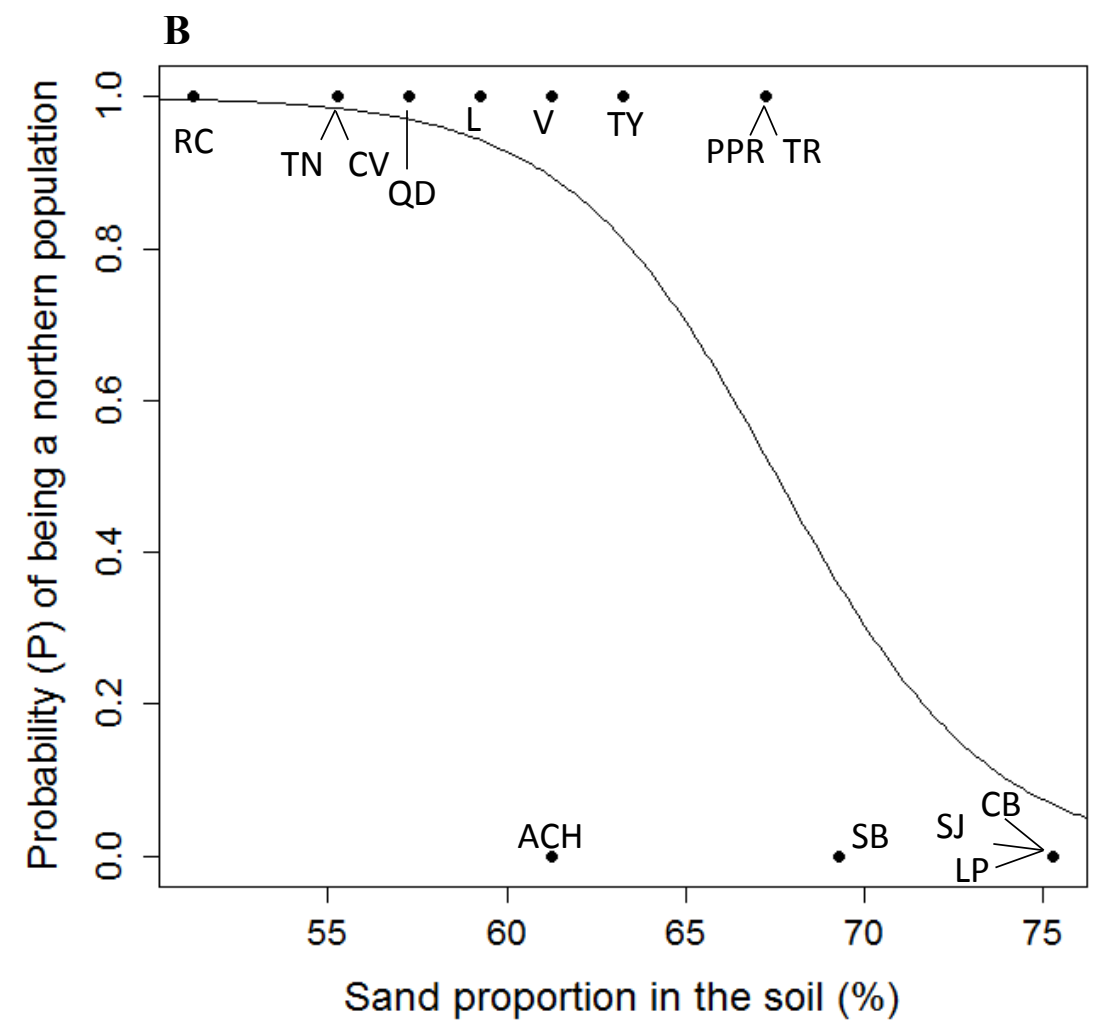


690 Figure 4 A and B. A) Logistic model between mean minimum temperature in the coldest month 691 (Mmin) vs. probability $(P)$ of being a northern population of Picea chihuahuana. B) Logistic 692 model between mean sand proportion (\%) vs. probability $(P)$ of being a northern population of 693 Picea chihuahuana. Abbreviations are defined in Table 1 and Figure 1.

694

695

696

697

698

699

700

701

702

703

704

705

706

707

708

709

710 


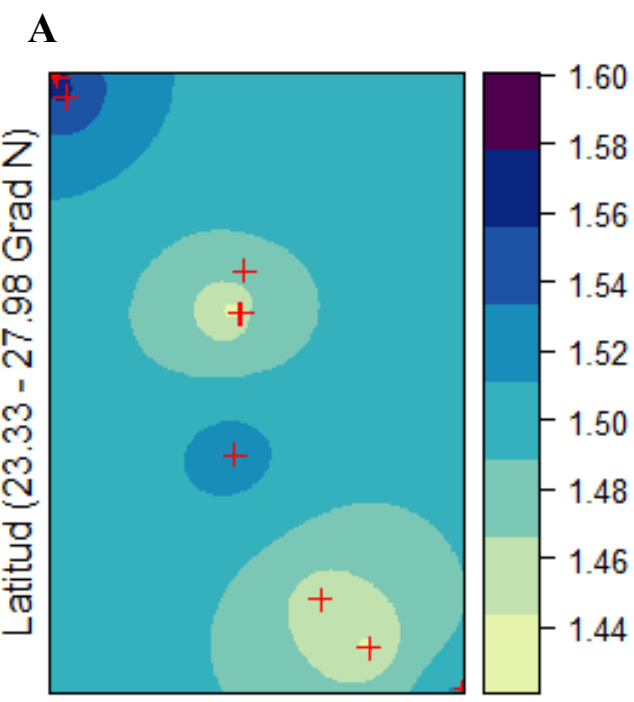

Longitud (104.75 - 107.77 Grad W) +
B

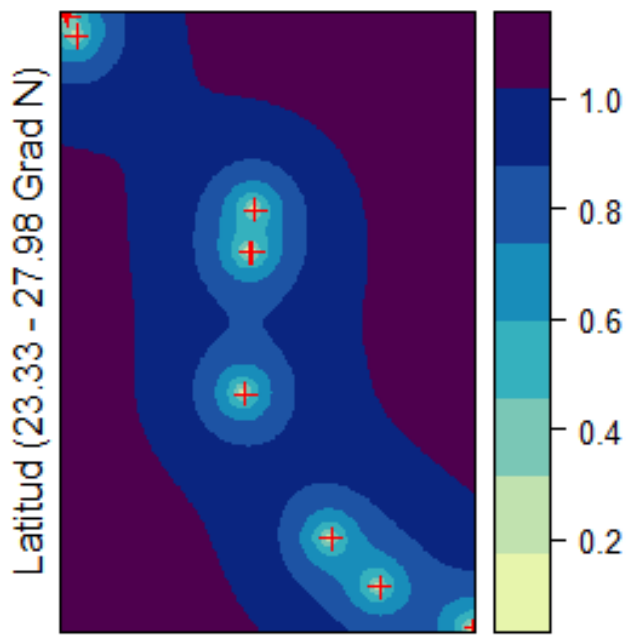

Longitud (104.75 - 107.77 Grad W) +

712

713 Figure $5 \mathrm{~A}$ and $\mathrm{B}$. Ordinary kriging analysis of the spatial genetic distribution of genetic

714 diversity $\mathrm{v}_{2}$ in $P$. chihuahuana based on 14 populations studied (marked with red crosses); A)

715 Kriging prediction (correlation between the observed and predicted values equals 0.84 ), $\mathrm{v}_{2}$ values

716 shown on the right-hand side, and B) Kriging standard error, error values shown on the right-

717 hand side. The exponential model was the best mathematical model for describing the 718 semivariance.

719

720

721

722

723

724

725

726

727

728 


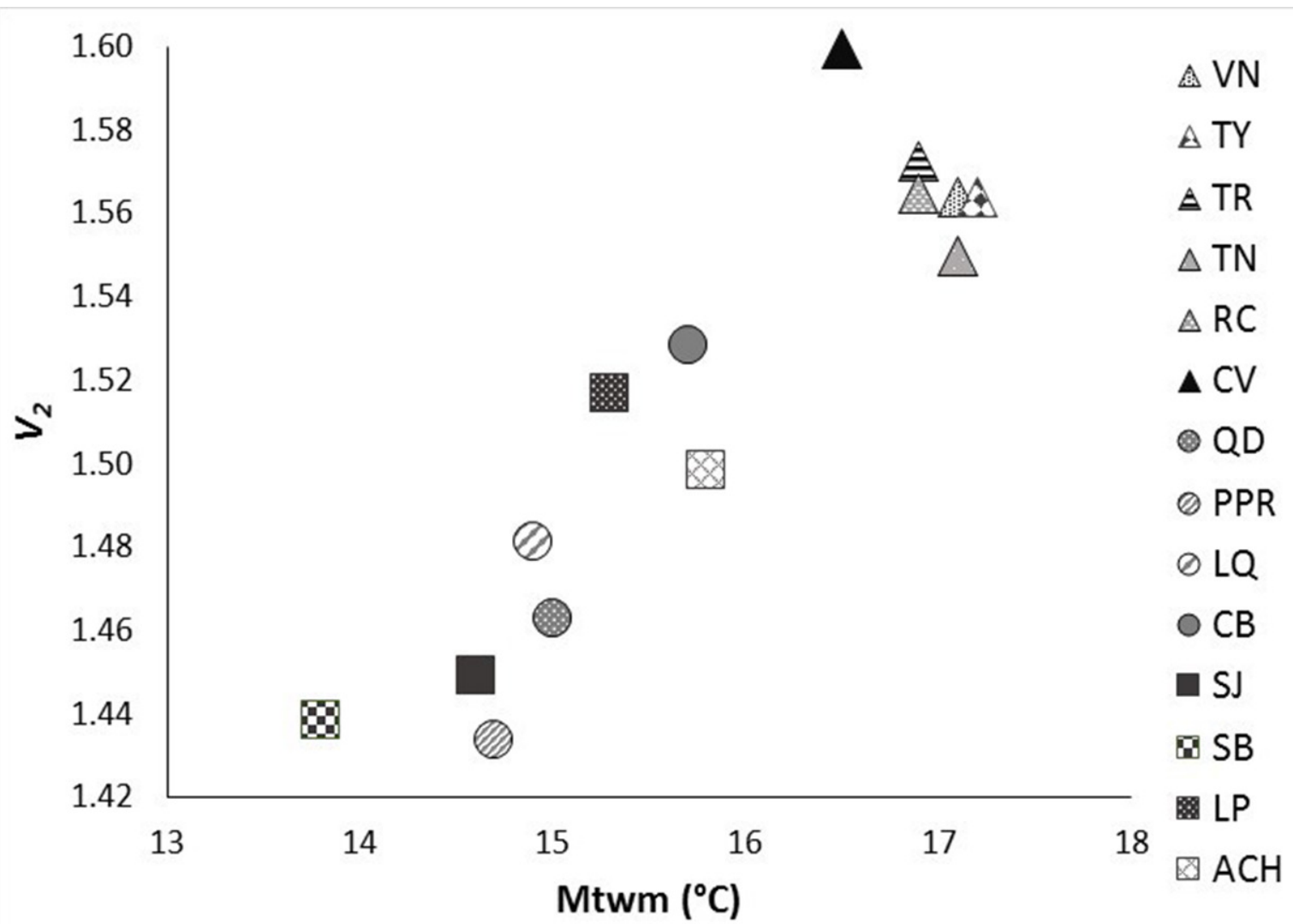

Figure 6. Relationship between genetic diversity $\left(\mathrm{v}_{2}\right)$ and mean temperature in the warmest month (Mtwm) in the 14 studied populations of Picea chihuahuana: La Tinaja (TN), El Ranchito (RC), El Cuervo (CV), Talayote (TY), Las Trojas (TR), El Venado (VN), La Quebrada (LQ), Paraje Piedra Rayada (PPR), Quebrada de los Duran (QD), Cebollitas (CB), San José de las Causas (SJ), Santa Bárbara (SB), Arroyo del Chino (ACH), La pista (LP). Triangles represent the geographically northern cluster. Circles represent the geographically central cluster. Squares represent the geographically southern cluster. 